\title{
Assessment of the Surface Water Quality: A Case of Wadi El-Kébir West Watershed, Skikda, North-East Algeria
}

\section{A. Lazizi $\uparrow$ and A. Laifa}

Laboratory Research of Soil and Sustainable Development, Department of Biology, Faculty of Sciences, Badji Mokhtar University of Annaba, B.P. 12, 23000 Annaba, Algeria

†Corresponding author: Asma Lazizi; laziziasma@gmail.com

Nat. Env. \& Poll. Tech. Website: www.neptjournal.com

Received: 17-12-2019

Revised: $27-12-2019$

Accepted: 28-03-2020

\section{Key Words:}

Western Wadi El-Kebir

Water quality

Eutrophication

Nitrogen

\begin{abstract}
The considerable increase in the amount of nitrogen in the surface water is a major environmental problem. It has become a great matter of worry because of the multiple environmental effects including eutrophication and health risks. The El-Kebir West watershed is a coastal plain in northeastern Algeria. This study aims to determine the physicochemical quality of waters of the western WadiEl-Kebir and its main tributariesand also to evaluate the spatiotemporal variabilityof its physicochemical quality in particular of mineral nitrogen during wet and dry periods. Four sampling campaigns were realized as follows: January 2015 and February 2016 corresponding to water high season and in March and September 2016 corresponding to the low season. The water samples were obtained from the seven stations located along western Wadi El-Kebir. Temperature, $\mathrm{pH}$,conductivity,dissolved oxygen, $\mathrm{SO}_{4}{ }^{2-}$, $\mathrm{PO}_{4}{ }^{3-}, \mathrm{NO}_{3}{ }^{-}, \mathrm{NO}_{2}{ }^{-}$and $\mathrm{NH}_{4}{ }^{+}$were measured either in situ or in the laboratory.A statistical treatment employingthe PCA method (The Principal Components Analysis) was applied for all the obtained results. It has been noticed that the S2 and S3 upstream stations are very rich in ammonium $\left(\mathrm{NH}_{4}{ }^{+}\right)$at the low water period with average values of $15.22 \mathrm{mg} / \mathrm{L}$ and $20.41 \mathrm{mg} / \mathrm{L}$, respectively. This study has shown the influence of seasonal variations and anthropogenic activities on the evolution of physicochemical settings, in general, and on mineral nitrogen in particular. In conclusion,the waters of Wadi El-Kebir were of an average to poor quality.
\end{abstract}

\section{INTRODUCTION}

Pollution affects a large part of our river systems. This is mainly due to the extremely rapid expansion of urban areas that necessarily discharge their treated or untreated wastewaters into river systems, as well as the multiplication of industrial establishments along rivers. But it is also the result of the development of agriculture, which is increasingly using chemical fertilizers, herbicides, insecticides and various pesticides.

The discharge of pollutants can profoundly modify the physicochemical components of receiving aquatic environments as well as the biocenoses inhabiting these environments (Pessonet al.1976). Among the sources of pollution, mineral nitrogen in its various forms $\left(\mathrm{NH}_{4}{ }^{+}\right.$, $\mathrm{NO}_{2}{ }^{-}$and $\mathrm{NO}_{3}{ }^{-}$) represents a direct (toxicity) or indirect (eutrophication) nuisance for the ecological balances of our rivers (Teissier 2001).

The present study takes as field the watershed of WadiKebir West in Ain Charchar, one of the sub-basins of the central Constantine region, located in north-east Algeria. The various economic activities dominated by agriculture and the agricultural processing industry and the continuous expansion of urban areas are sources of pollution of surface and groundwater in this watershed.

This study aims to assess the pollution of the waters of the Wadi El-Kébir-West and its main tributaries, to diagnose the watercourse eutrophication and its receiving environment.

\section{MATERIALS AND METHODS}

\section{Study Area}

Located in the north-east region of Algeria (Fig. 1), between the Filfila massif in the north and the Constantine mountains in the south, the watershed of the wadi El- Kebir West is part of the greatbasin pouring coasting Constantinois, extends over a total area of about $1130 \mathrm{~km}^{2}$, and is limited between latitudes $36^{\circ} 30^{\prime}$ and $37^{\circ} 00^{\prime}$ North and longitudes $7^{\circ} 00^{\prime}$ and $7^{\circ} 30^{\prime}$ East (Daifallah 2008). This basin has a water potential of about $90 \mathrm{Hm}^{3}$. The Wadi El -Kebir West is the main watercourse with a total length of about $43 \mathrm{~km}$. Its width varies between 20 and 50 meters and its main tributaries are WadiFendek and Wadi El Aneb.

The climate of the coastal area of the Skikda region is of the humid Mediterranean type. Its annual rainfall reaches 


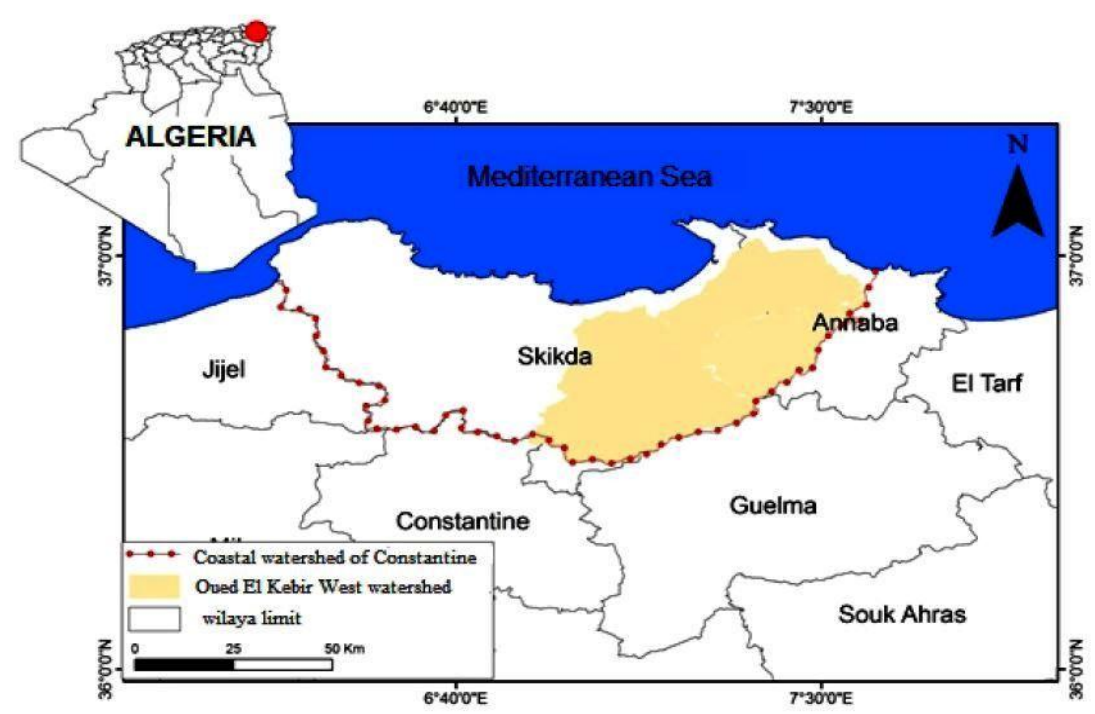

Fig. 1: Geographical location of the Wadi El-Kebir West watershed.

nearly $1300 \mathrm{~mm}$. This area is classified among the most watered regions in northeastern Algeria (Benrabah et al. 2013, Bouchareb et al. 2013).

\section{Water Sampling}

Water samples were collected at seven sampling points (stations) selected based on the hydrological importance of the tributaries, the urbanization of the watershed and the ease of access and collection of water samples in the Wadis (Fig. 2).

The geographical coordinates of these different GPS stations are given in Table 1.
The water samples were collected in the middle of the riverbed and introduced intopolyethene bottles previously rinsed with distilled water and the stationwater. They have been then stored at $4^{\circ} \mathrm{C}$ duringtransporting them to the laboratory of the Soil and Sustainable Development (Badji Mokhtar University Annaba) within the 24 hours of sampling.

\section{Water Analysis}

To gradually follow the evolution of water quality in the wadis during both the low and high water periods, seasonal monitoring has been adopted. A total of 4 sampling campaigns were carried out during 2015 and 2016

Table 1: Geographical coordinates of water abstraction stations.

\begin{tabular}{|c|c|c|}
\hline Stations & Coordinates & Station Description \\
\hline S1 : Wadi Mougger & $\begin{array}{l}\text { N } 36^{\circ} 42.095 \\
\text { E } 007^{\circ} 18.605^{\prime}\end{array}$ & $\begin{array}{l}\text { - Upstream of the watershed, } \\
\text { - One of the main effluents of the Oued El Kebir watercourse. } \\
\text { - Located in an urban area (region from Roknia to Bekkouche Lakhdar). } \\
\text { - Presence of thermal sources from which wastewater is discharged into the watercourse. }\end{array}$ \\
\hline S2 : Wadi Fendek & $\begin{array}{l}\text { N } 36^{\circ} 43.655^{\prime} \\
\text { E } 007^{\circ} 05.008^{\prime}\end{array}$ & $\begin{array}{l}\text { - Upstream of the watershed } \\
\text { - Azzaba Region }\end{array}$ \\
\hline S3 : Wadi Emchekel & $\begin{array}{ll}\text { N } & 36^{\circ} 44.642^{\prime} \\
\text { E } & 007^{\circ} 14.374\end{array}$ & $\begin{array}{l}\text { - Located in the inner part of the watershed of Oued El Kebir West. } \\
\text { - Agricultural and industrial area. }\end{array}$ \\
\hline S4 : Wadi El Kébir & $\begin{array}{l}\text { N } 36^{\circ} 44.468^{\prime} \\
\text { E } 007^{\circ} 26.125\end{array}$ & $\begin{array}{l}\text { - Urban and industrial area } \\
\text { - Located near the Hadjar Soud Cement Plant. }\end{array}$ \\
\hline S5 : Wadi Magroun & $\begin{array}{l}\text { N } 36^{\circ} 52.439^{\prime} \\
\text { E } 007^{\circ} 25.640^{\prime}\end{array}$ & $\begin{array}{l}\text { - Confluence of the Oueds Mougger and Emchekel (Ben Azzouz). } \\
\text { - diversified industrial area. }\end{array}$ \\
\hline S6 : Wadi Aneb & $\begin{array}{ll}\mathrm{N} & 36^{\circ} 52.384 \\
\mathrm{E} & 007^{\circ} 25.640\end{array}$ & $\begin{array}{l}\text { - Downstream of the watershed } \\
\text { - Urban and agricultural area. } \\
\text { - Length of this Oued greater than } 26 \mathrm{Km}\end{array}$ \\
\hline S7 : Wadi Ennkouche & $\begin{array}{l}\text { N } 36^{\circ} 58.185^{\prime} \\
\text { E } 007^{\circ} 15.637^{\prime}\end{array}$ & $\begin{array}{l}\text { - Located } 200 \text { meters from the entry into the sea. } \\
\text { - Agricultural area characterized by the existence of marshes. }\end{array}$ \\
\hline
\end{tabular}




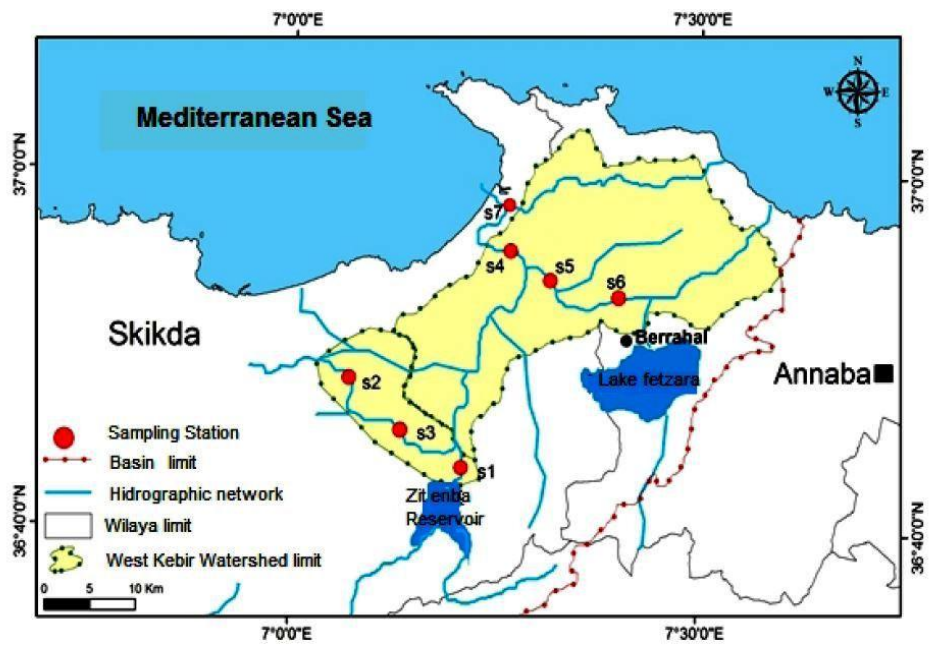

Fig. 2: Location of water sampling stations in the Wadi El-Kebirwest watershed.

(two during the wet season and two during the dry season), i.e. January 2015-February 2016 and May 2016September 2016.

For each sample collection, in situ measurements of temperature, $\mathrm{pH}$, electrical conductivity and dissolved oxygen were performed to determine certain characteristics of the sampling environment. Thesewere measured using a multi-parameter (HANNA instruments HI 9828).

The chemical parameters were determined byusing the standardized methods of Rodier (1978) using a spectrophotometer. Nitrate ions $\left(\mathrm{NO}_{3}{ }^{-}\right)$were determined by the sodium salicylate method and nitrite ions $\left(\mathrm{NO}_{2}^{-}\right)$by the Zambelli reagent method. The determination of ammonium ions $\left(\mathrm{NH}_{4}{ }^{+}\right)$was carried out by the Nessler reagent method. The orthophosphate $\left(\mathrm{PO}_{4}{ }^{3-}\right)$ dosing was analysed by the ammonium molybdate spectrophotometric method.The sulphate ion $\left(\mathrm{SO}_{4}{ }^{2-}\right)$ was determined by gravimetry after precipitation in the form of barium sulphate.

We have treated the data of the physicochemical analysis by the statistical method called Principal Component Analysis (ACP) using XLSTAT 2016 software.

\section{RESULTS AND DISCUSSION}

\section{Physicochemical Characteristics}

Water temperature is an important factor in the aquatic environment because it regulates almost all physical, chemical and biological reactions (Nouayti et al.2015).

The water temperature values of Wadi El -Kebir West vary according to the seasonal rhythm, with a maximum value of $23.5^{\circ} \mathrm{C}$ (Station S2) in the dry period (4th campaign) and a minimum value of $11.5^{\circ} \mathrm{C}$ (Station S4) in wet period ( $1^{\text {st }}$ campaign) (Fig. 3a). The temperature of surface waters (rivers, lakes and reservoirs) varies greatly according to the season and can go from $2{ }^{\circ} \mathrm{C}$ in winter to $30^{\circ} \mathrm{C}$ in summer (Potelon \& Zysman 1998).

Electrical conductivity indicates the ability of an aqueous solution to conduct electrical current. It represents the total content of the mineral salts present dissolved in an aqueous solution (Ayad 2016). The minimum value $(198 \mu \mathrm{S} / \mathrm{cm})$ was observed at station S6 during the wet season (2nd season). The highest conductivity value $(3024 \mu \mathrm{S} / \mathrm{cm})$ measured at station S7 (downstream of the wadi) in the dry period (3rd campaign) indicates high mineralization probably due to urban wastewater discharges and agricultural leaching.

The temporal variation in the electrical conductivity of the waters of Wadi El-Kebir shows a decrease during the high water period (Fig. 3b). Abundant rainwater during this period would be the main factor in reducing the electrical conductivity of the water (Doubi et al. 2013) in Wadi El-Kebir West.

The $\mathrm{pH}$ of the water measures the concentration of $\mathrm{H}^{+}$ions found in the water. It summarizes the stability of the balance established between the different forms of carbonic acid and it is linked to the buffer system developed by carbonates and bicarbonates (Makhoukh et al. 2011). The observed values do not show any significant variations and tend to be basic with a minimum of 7.37 at station $\mathrm{S} 4$ in the 1st campaign and a maximum of 8.85 at stations S3 and S5 (3rd campaign) (Fig. 3c).

The increase in $\mathrm{pH}$ during the high water period is thought to be related to the dissolution of carbonate from limestone rocks and the addition of humic acids during soil leaching (Bou Saab 2017). 
3a)

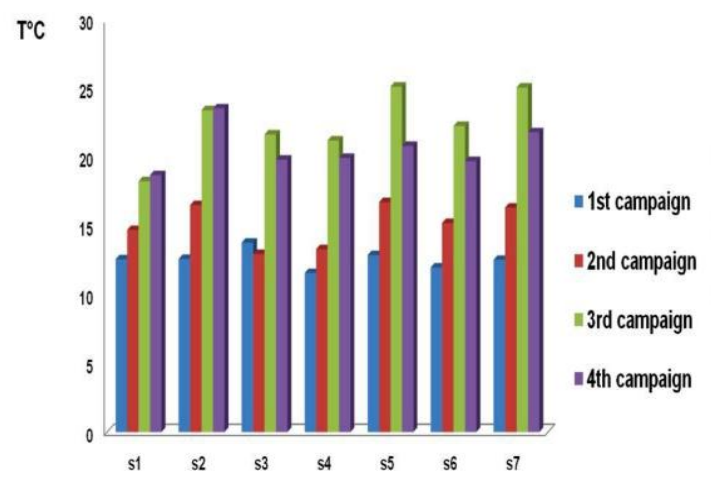

Stations

$3 c)$

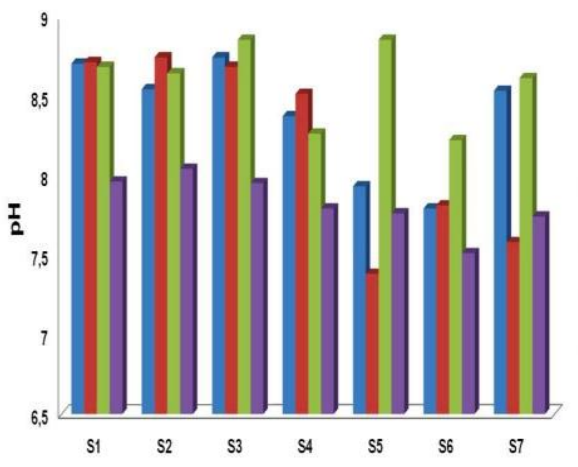

Stations
$3 b)$

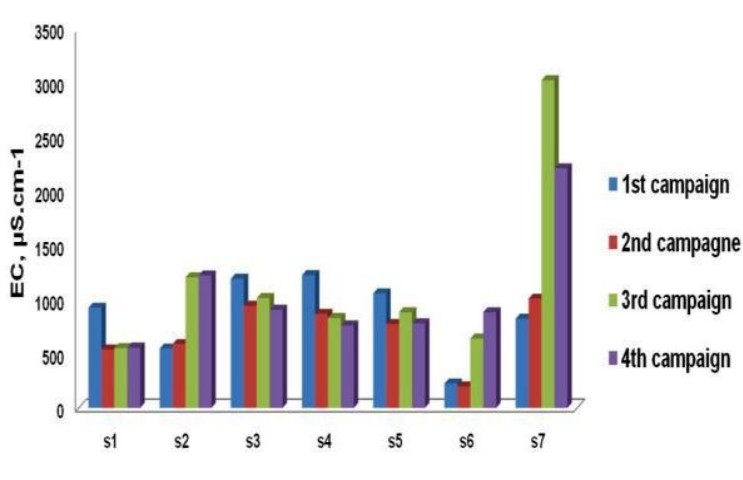

Stations

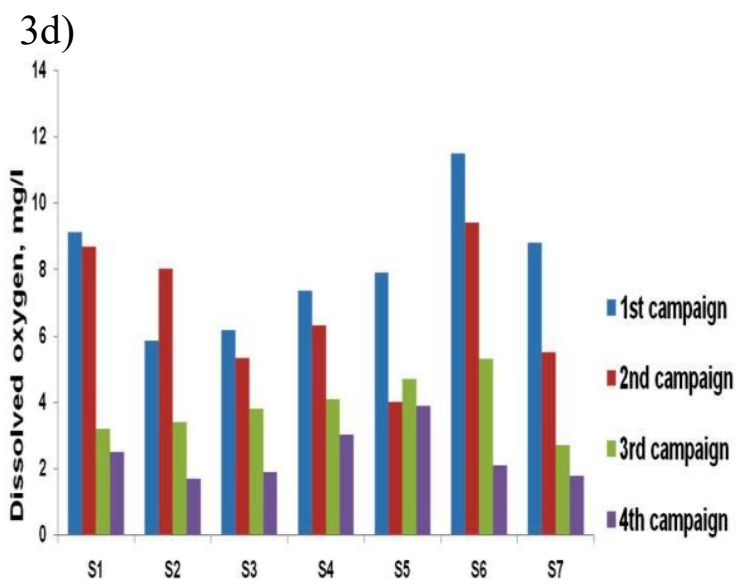

Fig. 3:Spatial and temporal variation of (a) temperature, (b) electrical conductivity, (c) pHand (d) dissolved oxygen in the waters of the Wadi El-Kebir West.

The quantification of the concentration of dissolved oxygen in water (DO) in a hydro-system is a fairly important factor because it is involved in the majority of chemical and biological processes in these aquatic areas. Its value provides us with information on the degree of pollution and therefore on the degree of self-purification of a watercourse (Makhoukh et al. 2011).

In our study, the seasonal evolution of dissolved oxygen shows higher concentrations in wet periods than in dry periods. Indeed, the reported levels (Fig. 3d) range from 1.8 $\mathrm{mg} / \mathrm{L}$ (S7, 4th campaign) to $11.5 \mathrm{mg} / \mathrm{L}$ (S6, $1^{\text {st }}$ campaign). The concentration of dissolved oxygen in natural waters can be influenced by several factors; the increase in this parameter in the waters of Wadi El-Kebir would be related to rainwater loaded with atmospheric oxygen and strong flow rates promoting air diffusion in the waters of rivers (Makhoukh et al. 2011).

The low dissolved oxygen levels recorded in the dry period (S2, S3 and S7) are probably related to the high organic loads of urban discharges (Reggam et al. 2015). This situation is favourable to the self-purification of the wadi and the oxidation of organic and ammoniacal nitrogen to nitrate ion.

Nitrate is naturally present and soluble in soil, entering soil and groundwater and discharging into watercourses. It generally comes from the decomposition of organic matter by bacterial oxidation of nitrites and is thus the ultimate product of nitrification. However, it is also synthetically provided by fertilizers and is one of the factors contributing to the degradation of water quality (Abboudi et al.2014). 
The histogram of nitrate ion concentrations in the waters of Wadi El- Kebir West (Fig. 4a) shows a slight variation in these concentrations, which oscillate between the minimum value of $0.2 \mathrm{mg} / \mathrm{L}$ registered at station $\mathrm{S} 6$ (1st campaign) and the maximum value found at station $\mathrm{S} 1$ (4th campaign) with $14.21 \mathrm{mg} / \mathrm{L}$. These results do not exceed the accepted standard for surface water of $50 \mathrm{mg} / \mathrm{L}$ (ABH 2010).

Nitrite, also called nitrous nitrogen, it is an intermediate product between nitrate and ammonium ion in nitrification and denitrification processes. This form of mineral nitrogen, the least oxygenated and most unstable, is an ecotoxic precursor in aquatic environments and a human health risk. Nitrites are spread in soil, water and plants but in relatively small quantities (Aissaoui 2012).

The highest concentration $(1.04 \mathrm{mg} / \mathrm{L})$ was recorded at station S5 in the 3rd campaign (dry season) (Fig. 4b). The presence of nitrites in significant quantities in the waters of the watercourse would indicate contamination resulting from the discharge of wastewater and an oxygen deficit in the environment and/or a reduction in nitrates by organic matter (Benrabah et al. 2013).

The found values do not exceed the accepted standard for surface water $1 \mathrm{mg} / \mathrm{L}(\mathrm{ABH} 2010)$, except at station 5 (3rd campaign), but they indicate pollution of the waters of Wadi El-Kebir.

Ammoniacal nitrogen is a good indicator of the pollution of watercourses by urban effluents. It is one of the links in the complex nitrogen cycle in its primitive state. It is a water-soluble gas. In surface waters, it comes from nitrogenous organic matter and gaseous exchanges between water and the atmosphere(Makhoukh et al. 2011)

Analysis of the ammonium profile (Fig. 4c) shows that the levels are between the minimum value of $0.44 \mathrm{mg} / \mathrm{L}$ recorded at station S2 (1st campaign) and the maximum value found at station S3 with $30.98 \mathrm{mg} / \mathrm{L}$ (4th campaign). Ammonium values found in wet weather are lower than those found in dry weather. The effect of dilution by rainwater is the good oxygenation of the waters of the wadi leading to the oxidation of nitrogen so that these values are consistent with the values of dissolved oxygen and the values of nitrate ion concentrations in the winter period (Debieche 2002). In natural waters, the detection of ammonium in large quantities ( $5 \mathrm{mg} / \mathrm{L}$ ) is a pollution criterion (Dussart 1966, Bengherbia et al. 2014)

Phosphate $\left(\mathrm{PO}_{4}{ }^{3-}\right)$ is the result of the degradation by bacteria of organic phosphorus contained mainly in wastewater. They can also be introduced in significant quantities into watercourses by runoff from agricultural fields enriched with phosphate fertilizers. They are also involved in the eutrophication of watercourses.
The analytical results illustrated by (Fig. 4d) show that the concentrations of orthophosphate ions in the waters of Wadi El-Kebir West vary between $0 \mathrm{mg} / \mathrm{L}$ (S6) in the 1st campaign and $1.92 \mathrm{mg} / \mathrm{L}$ (S4) in the $3 \mathrm{rd}$ campaign. This variation has a relatively increasing trend in dry periods. The high concentrations of orthophosphates upstream of the Wadi El-Kebir are linked to urban discharges from neighbouring urban areas and wastewater from the Hammams situated in this area.

Surface waters contain sulphate ion in variable quantities; concentrations are generally between $2.2 \mathrm{mg} / \mathrm{L}$ and $58 \mathrm{mg} / \mathrm{L}$ (Meybeck et al. 1996, Abboudi et al. 2014). In the analyzed waters of Wadi El-Kebir West, they are variable and oscillate between $0 \mathrm{mg} / \mathrm{L}$ (S5 and S6) in the first campaign and 87.5 $\mathrm{mg} / \mathrm{L}$ (S7) in the 4th campaign (Fig. 4e).

\section{Statistical Analysis}

The Principal Component Analysis (ACP) is a tool for analysis of data which makes it possible to explain the structure of the correlations by using linear combinations of the original data. The ACP aims to present, in a graphical form, the maximum of contained information in data table based on the principle of double projection on the factorial axes(Ramdani\&Laifa 2017). This method is widely used to interpret hydrochemical data(N'diaye et al. 2013).

It allowed us to quickly extract an interesting amount of information from a set of dimensional data using two simple graphs; the correlation circle and the observation graph. The data cover all 7 water sampling stations in Wadi El-Kebir West in two periods: wet season (high water) and dry season (low water).

Nine variables were treated; $\mathrm{pH}$, temperature, electrical conductivity (EC), dissolved oxygen, sulfate ion, nitrate ion, nitrite ion, ammonium ion and orthophosphate ions.

\section{Period of High Waters}

The major part of the information is explained by the factor axes F1 and F2. These axes show the correlations between the studied variables that are related to the wet season.The analysis of the factorial plan F1 and F2 shows that $76.28 \%$ of the variance is expressed (Fig. 5).

The factorial plan $\mathrm{F} 1$ is expressed at $47.94 \%$; this axis is mainly represented by $\mathrm{SO}_{4}{ }^{2-}, \mathrm{PO}_{4}{ }^{3-}, \mathrm{NH}_{4}{ }^{+}, \mathrm{NO}_{2}{ }^{-}$as well as $\mathrm{pH}$ and $\mathrm{EC}$. It reflects both mineralization and organic pollution of water.Axis F2 is expressed at $28.79 \%$ and represented by temperature, $\mathrm{NO}_{3}{ }^{-}$and $\mathrm{OD}$ in the negative direction. It reflects a significant presence of oxidized nitrogenous forms $\left(\mathrm{NO}_{3}{ }^{-}\right)$. 
4a)

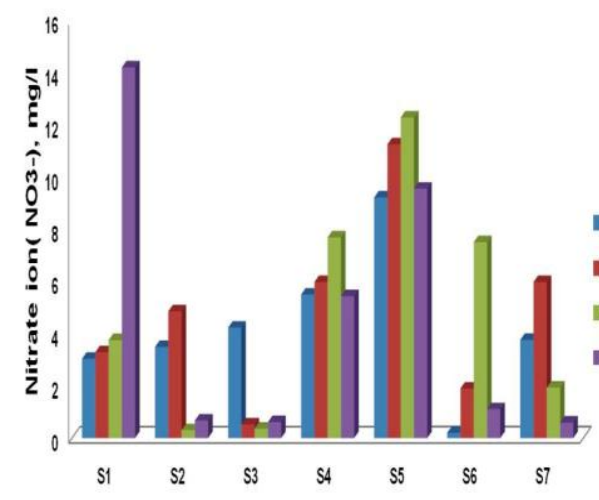

Stations

4c)

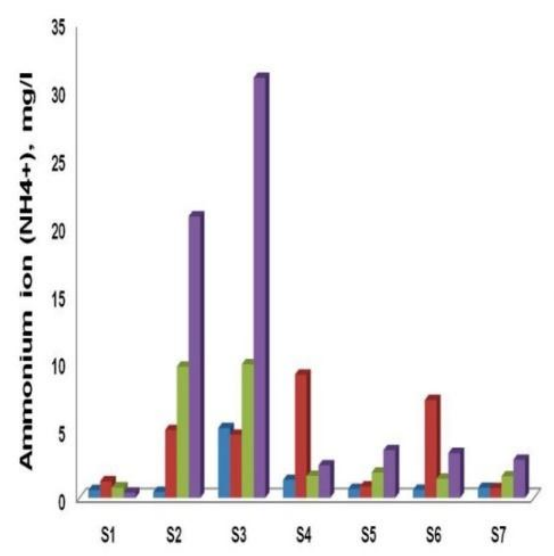

Stations 4b)

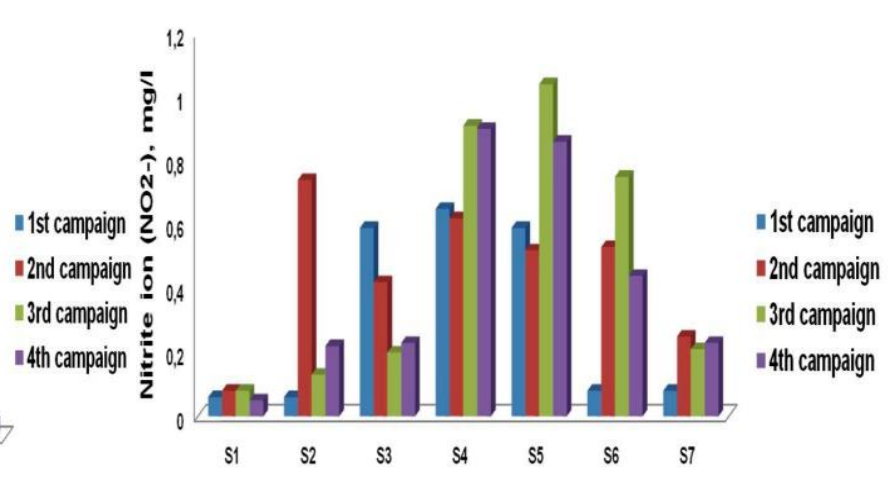

Stations

$4 d)$

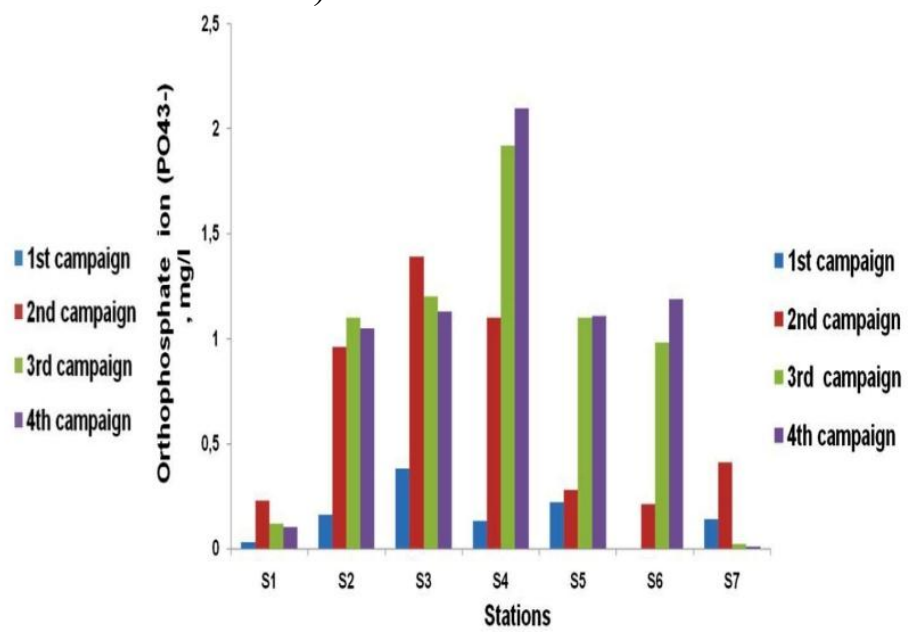

$4 \mathrm{e})$

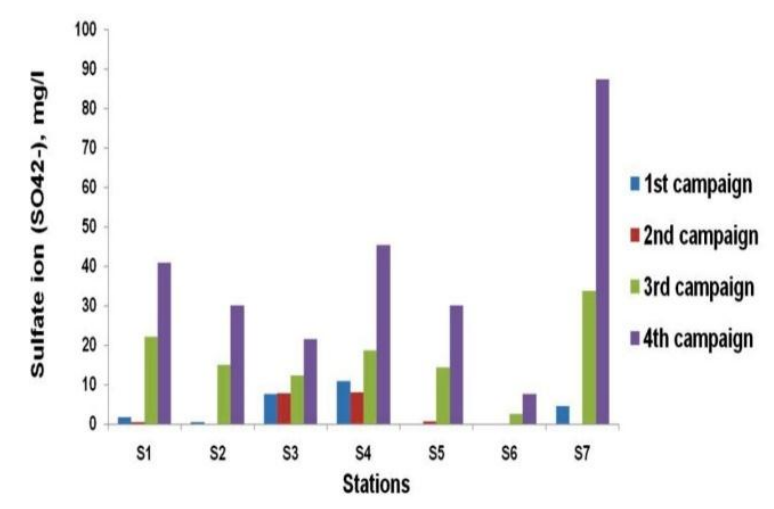

Fig. 4: Spatial and temporal variation of the concentration of (a) nitrate ion, (b) nitrite ion, (c) ammonium, (d) orthophosphates and(e)sulfate in the waters of Wadi El-Kebir West. 


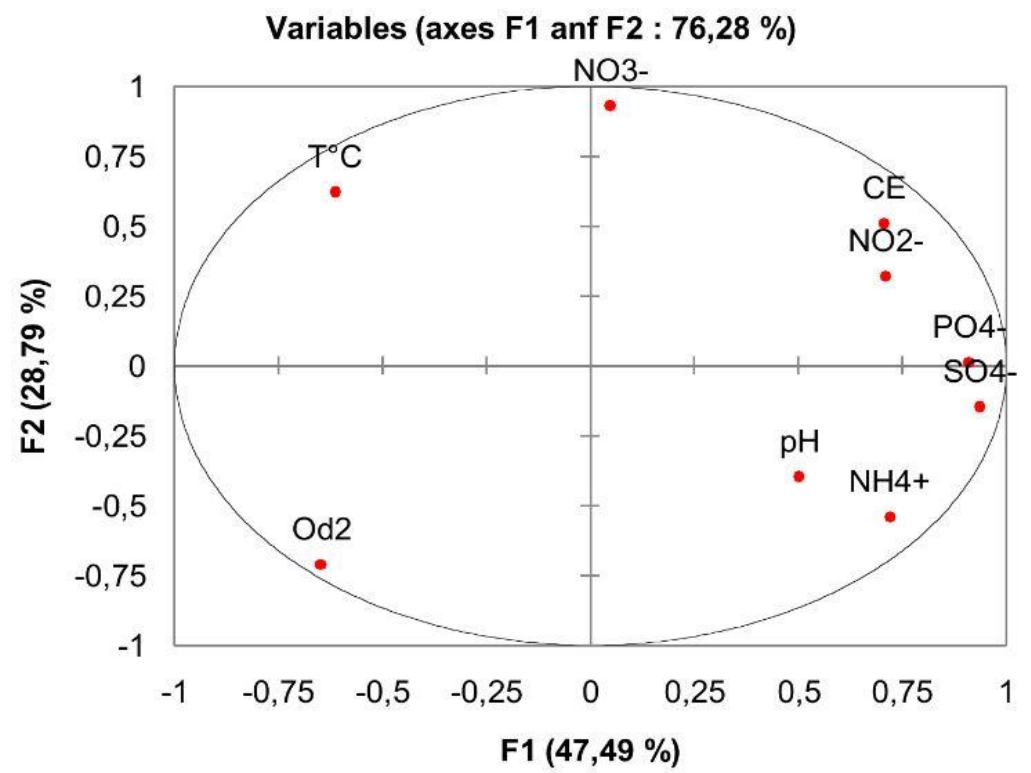

Fig. 5: Projection of the physicochemical parameters of the water on plan F1 and F2 (High water period).

\section{Period of Low Waters}

The factorial plan F1 and F2 shows that $65.79 \%$ of the total information is expressed (Fig. 6). Axis F1 represents $34.16 \%$ of the information. It is expressed towards its positive pole by $\mathrm{OD}$, $\mathrm{NO}_{3}{ }^{-}, \mathrm{NO}_{2}{ }^{-}, \mathrm{PO}_{4}{ }^{3-}$ and in the negative sense by temperature and EC. These variables describe both eutrophication and water mineralization. Axis F2 is expressed at $22.64 \%$ and represented by $\mathrm{NH}_{4}{ }^{+}, \mathrm{pH}$ and $\mathrm{SO}_{4}{ }^{2-}$, reflecting an organic matter load.
With regard to the representation of stations, the ACP results show that the different stations are positioned (on axes F1 and F2) according to the degree of pollution of their waters.

\section{Period of High Waters}

The most polluted study stations S3 and S4 are located on the positive side of the F1 axis. They are characterized by

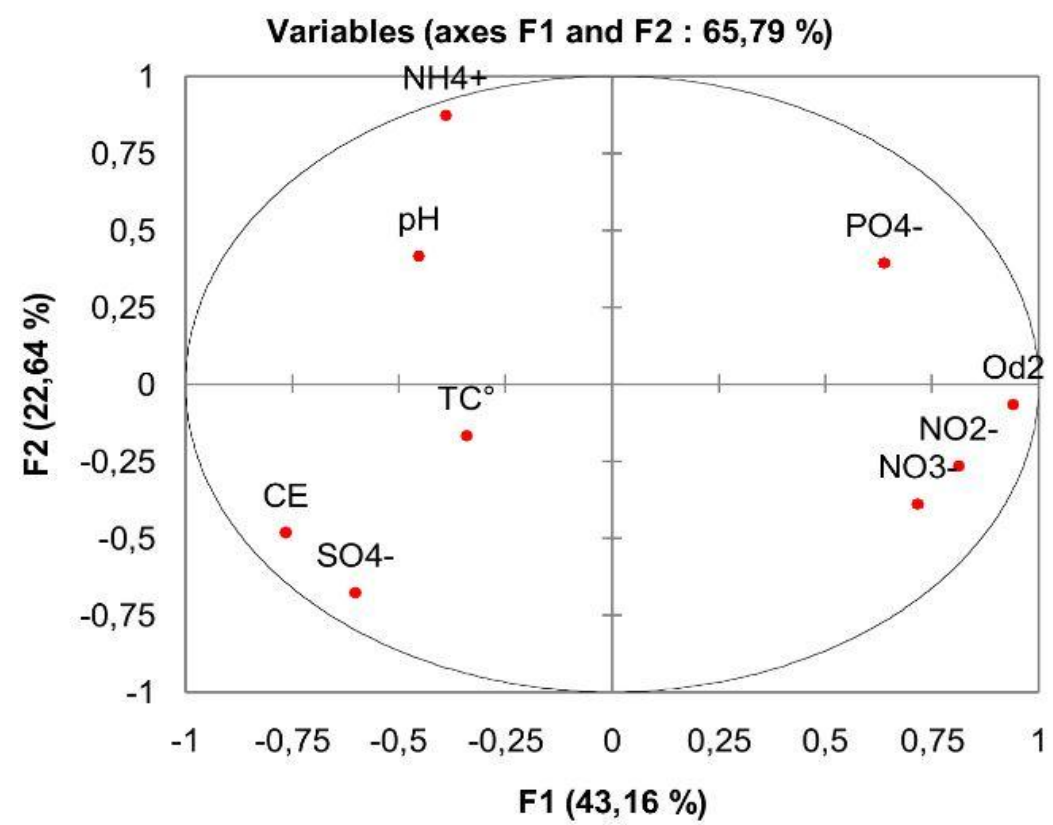

Fig. 6:Projection of the physicochemical parameters of the wadi waters on plan F1 and F2 (Low water period). 
high concentrations of $\mathrm{SO}_{4}{ }^{2-}, \mathrm{PO}_{4}{ }^{3-}, \mathrm{NH}_{4}{ }^{+}, \mathrm{NO}_{2}{ }^{-}$, high $\mathrm{pH}$ and $\mathrm{EC}$ values, and low concentrations of OD. Overall, they are the most loaded with organic material from domestic waste, agricultural waste and cement from the Hadjar Soude factory. Stations S1 and S6 are located on the negative side.

Stations S2, S5, S7 are positioned on the positive side of the $\mathrm{F} 2$ component characterized by a significant presence of $\mathrm{NO}_{3}{ }^{-}$(Fig. 7).

\section{Period of Low Waters}

Stations S4, S5 and S6 are located on the positive side of axis $\mathrm{F} 1$ and contain large amounts of nutrients $\left(\mathrm{NO}_{3}{ }^{-}, \mathrm{NO}_{2}{ }^{-}\right.$ and $\mathrm{PO}_{4}{ }^{3-}$ ) from discharges from agricultural activities and urban wastewater. Station S7, located downstream of Wadi El-Kebir, is characterized by high electrical conductivity. Stations S2 and S3 upstream of the wadi are presented on the positive part of the factorial axis F2. They are the richest in $\mathrm{NH}_{4}{ }^{+}$ion (Fig. 8).

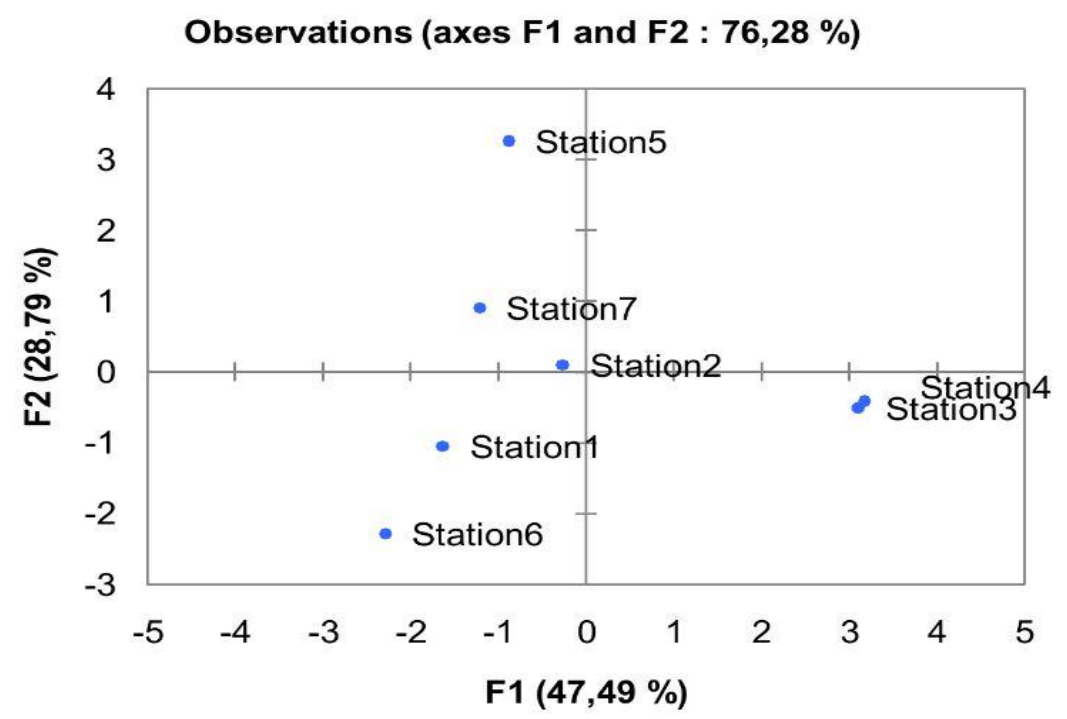

Fig. 7: Representation of the water sampling stations on the factorial plan F1 and F2 (high water period).

Observations (axes F1 and F2 : 65,79 \%)

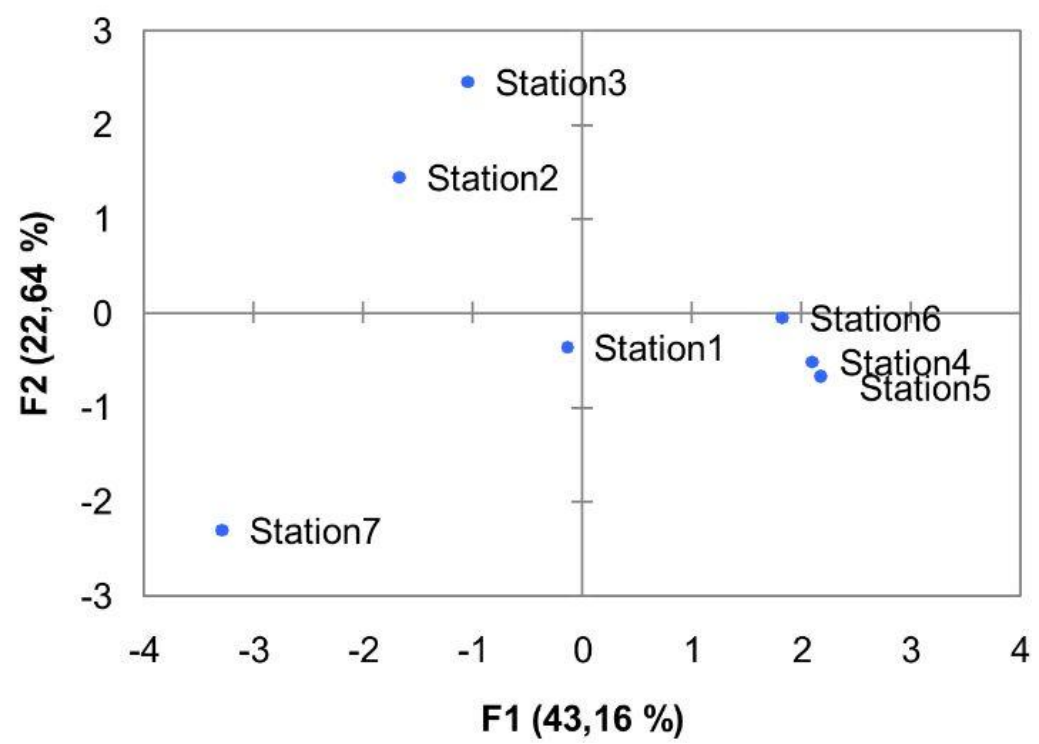

Fig. 8: Representation of the wadi water sampling stations on the plan factorial F1 and F2 (low water period). 


\section{CONCLUSIONS}

In the light of the results of physicochemical analyses carried out on the waters of Wadi El-Kebir West, a degradation of water quality has been observed.The study of the spatial and temporal evolution of the measured parameters shows a significant difference between the sampling stations and between high water and low water periods. However, there is a degradation of quality in dry weather which results in high values of some parameters. This can be explained by the low flows of the wadis during this period, which corresponds to a phase of concentration and accumulation of degradation products of the materials contained in the waters of the wadi.

The statistical treatment of physicochemical data by analysing the main components allowed us to differentiate a zonality of water quality in the sequence of the wadi under study.The sampling stations located upstream and in the middle part (Azzaba, Ain Charchar and Ben Azouz plains) are the most affected by pollution linked to anthropogenic activities, in particular, the infiltration of wastewater (urban and industrial) and the use of chemical fertilizers in agriculture. Strong mineralization was detected downstream of the wadi (station 7) during the dry period.

Overall, the water quality of Wadi El-Kébir West is between the middle to poor classes. As a result, the control and preservation of this important watercourse become essential because its degradation constitutes an environmental and health risk. The most appropriate solution to this problem would be to set up wastewater treatment plants.

\section{REFERENCES}

Abboudi, A.,Tabyaoui, H. And El Hamichi,F.2014.Study of the physicochemicalquality and metallic contamination of surface waters of the Guigou watershed, Morocco.European Scientific Journal. 23:18577431.

Agence De Bassin Hydrographique De Constantine «ABH» (Constantine River Basin Agency).2010. Surface Water Quality in the Constantine Coastal and Highlands Basins 2004-2007. The Agency's Workbooks. Ministry of Water Resources.

Aissaoui, A. 2012. Evaluation of the level of contamination of the Grouz hammam dam water in the Oued Athmania region (Mila wilaya) by agricultural activities.. Magister's thesis. Mouloud Mammeri Tizi-Ouzou University, $133 \mathrm{p}$.

Ayad, W. and Kahoul,M. 2016. Assessment of the physicochemical and bacteriological quality of well water in the region of El-Harrouch (N.E. -Algeria).J. Mater. Environ. Sci.,7: 1288-1297.

Bengherbia, A., Hamaidi, F., Zahraoui, R., Hamaidi, M S. andMegateli, S. 2014. Impact of wastewater discharges on the physicochemical and bacteriological quality of the Beni Aza wadi (Blida, Algeria). Lebanese Science Journal, 15: 39-51.

Benrabah, S., Bousnoubra, H., Kherici, N. and Cote, M. 2013. Characterization of water quality in the Kebir Quest oued (North East Algeria). Revue des Sciences et de la Technologie; Synthese, 26: 30-39.

Bouchareb, N. 2013.Nitrogen, phosphorus and silicon transfers and geochemistry from the Kebir-Rhumel, West Kebir and Saf-saf basins to the coast.MSc Thesis. Badji Mokhtar Annaba University.

Bou Saab, H., Nassif, N., ElSamrani, A G., Daoud, R., Medawar, S. and Ouaïni, N. 2017.Monitoring the bacteriological quality of surface waters (Nahr Ibrahim River, Lebanon). Revue Science de l'eau, 20: 341-352.

Daifallah, T. 2008.Water Resources And Integrated Management in the Oued El Kebir West Watershed (North East Algeria).Magister's thesis. Badji Mokhtar Annaba University.

Debieche, T. H. 2002.Evolution of water quality (salinity, nitrogen and heavy metals) under the effect of saline, agricultural and industrial pollution. Application to the low plain of the Seybouse-North-East Algeria.M.Sc. thesis. Badji Mokhtar Annaba University.

Doubi, M., Dermaj, A., Ait Haddou, B., Chebabe, D., Erramli, H., Hajaji, N. and Etsrhiri, A. 2013.Contribution to the study to the physico-chemical study of Oued Moulouya and an influent in the Outat El Haj region. Larhys Journal, 16:91-104.

Dussart, B.(ed.)1966.Limnologie. L'étudeDes EauxContinentales. Gauthier-Villars ed.Paris, p. 677.

Makhoukh, M., Sbaa, M., Berrahou, A. and Clooster, M. Van 2011. Contribution to the physico-chemical study of the surface waters of the Moulouya Oued (Eastern Morocco).Larhyss Journal, 09:149-169.

Meybeck, M., Friedrich, G., Thomas, R. and Chapman, D. (ed.)1996.Water Quality Assessments: A Guide to the Use of Biota, Sediments and Water in Environment Monitoring.Chapman E \& FN Spon, London.

N'diaye a,D., OuldSid'Ahmed, M., OuldKankou, A., Sarr, D. and Lo, B. 2011. Contribution of the main components analysis to the assessment of the colour of Nouakchott city effluents.Larhyss Journal,09:139-147.

Nouayti, N., Khattach, D. and HilalI, M. 2015. Assessment ofphysico-chemical quality of groundwaterof the Jurassic aquifers inhigh basin of $\mathrm{Ziz}$ (Central High Atlas, Morocco). J. Mater. Environ. Sci., 6(4): 1068-1081.

Pesson, P., Leynaud, G., Riviere, J., Cabridence, R., Bovard, P., G. Tuffry, G., Vivier, P., Laurent, P., Angely, N., Descy, J P., Wattez, J R. andVerneaux, J. (ed.)1976.La Pollution Des EauxContinentales. Incidence Sur Les BiocénosesAquatiques. Ed. Gauthier-Villars. Paris, 285p.

Potelon, J. L. and Zysman, K. (ed.)1998. Le Guide DesAnalyses de l'eauPotable. Edition La Lettre du CadreTerritorial, Voiron, France.

Ramdani, H. and Laifa, A. 2017. Physicochemical quality of Wadi Bous namoussasurface waters (Northeast of Algeria). Journal of Water and Land Development,35:183-191.

Reggam, A., Bouchelaghem, H. and Houhamdi, M. 2015. Physicochemical quality of the waters of the Oued Seybouse (North-East Algeria): Characterization and analysis in main components. Journal. Mater. Environ. Sci., 6(5):1417-1425.

Rodier, J. (ed.) 1978.L'analyse de l'eau: EauxNaturelles, EauxRésiduaires, Eau De Mer; Chimie, Physico-Chimie, Bactériologie, Biologie. Dunod Tech, Paris, p. 1135.

Teissier, S. 2001. Assessment of nitrogen transformations in rivers. Methodological developments of the measurement of fluxes at the sediment-water column interface and applications (sediments, epilithic biofilms in the river Garonne). University Toulouse III,pp. 212. 